\title{
Indigenizing Digital Literacies: Community Informatics Research with the Algonquin First Nations of Timiskaming and Long Point
}

\author{
Rob McMahon, Tim Whiteduck, Arline Chasle, Shelley Chief, Leonard Polson, \\ Henry Rodgers
}

\begin{abstract}
Community-engaged digital literacies initiatives can greatly benefit from knowledge and practices developed by Indigenous peoples. In this paper, we describe a research project to develop digital literacies with two Algonquin First Nations in Quebec: Timiskaming and Long Point. This project reflects a First Mile approach to Community Informatics, informed by the theoretical framework of Indigenous resurgence and by engaged research methodologies. In telecommunications and broadband terminology, communities are typically framed as the 'last mile' of development. The First Mile approach challenges this situation by encouraging projects that emerge from the locally determined needs of collaborating communities, who gain ownership and control of processes and outcomes. Drawing on community-engaged research methodologies, university-based researchers facilitate this work while community-based researchers integrate data collection, analysis, and public outreach activities into the lived realities of community members. We discuss how digital literacies projects can benefit from the theoretical framework of Indigenous resurgence, which stresses the daily practices that support the continual renewal of Indigenous communities.
\end{abstract}

KEYWORDS information and communication technologies; community-engaged research; indigenous peoples; digital literacies; First Mile; Timiskaming First Nation; Long Point First Nation

Digital literacies initiatives can greatly benefit from knowledge and practices developed by Indigenous peoples. Recent developments in the study of digital literacies stress the need to encompass social practices as well as technical skills and knowledge: that is, how people and communities can effectively shape and use Information and Communications Technologies (ICT). Gillen and Barton (2010) write that: "Digital literacies are always dynamic - in part because technology is perceptibly developing so fast in front of our eyes - but also because human purposes continue to develop and are reshaped in collaboration" (p.8). From this perspective, digital literacies are grounded in - and emerge from - the many ways that people collectively make meaning through their ongoing interactions with ICT.

Indigenous theorists of resurgence illustrate how all kinds of daily practices contribute 
to the continual renewal of Indigenous communities by embedding Indigenous cultures in different aspects of life (Alfred \& Corntassel, 2005; Simpson, 2011). This observation can be seen in a number of contexts, including in the development and use of ICT and digital resources by Indigenous peoples (Haas, 2014). For example, Beaton and Campbell (2014) demonstrate how First Nations are cultivating resilience through the daily use of online applications, social media and broadband-enabled public services by continually shaping and using these digital tools in ways that build on the knowledge and experience held by members of communities. Building on this work, in this paper we describe a collaboration among researchers from two Algonquin First Nations in Quebec, a researcher from the University of New Brunswick (UNB) - now at the Faculty of Extension in the University of Alberta - and the director of technology at the First Nations Education Council (FNEC). These partners aimed to develop a flexible digital literacies methodology and toolkit that can be taken up, modified, adapted or dropped according to local needs and interests. ${ }^{1}$

Our process involved a long-term collaboration with local leadership, education directors, community research coordinators, and youth. ${ }^{2}$ Project partners set out to identify knowledge, skills, data and outcomes associated with digital literacies that are relevant to the needs of community members. In the course of designing and implementing household surveys to research these issues, we held ongoing discussions on the nature and focus of research; engaged community members as research participants; and outlined agreements concerning research data, analysis and outputs. Once data was collected we analyzed it together, discussing how to best leverage our findings for both academic and community use. Finally, we explored how the two projects might inform one another by sharing experiences, resources and lessons learned among project participants in the two communities.

We encountered many divergences in the course of this work. These included shifting project priorities, changes in team composition, and challenges in on-the-ground data collection and analysis. Our experience confirms the need for a dynamic, flexible project methodology that incorporates long-term capacity building as well as concrete research outcomes. This observation is consistent with other scholarship on community engaged ICT research (Ramirez, Aitkin, Kora \& Richardson, 2005; Hollander, 2009; Lang, Stillman, Linger, Dalvean, McNamara, McGrath \& Collins, 2012; McKemmish, Burstein, Faulkhead, Fisher, Gilliland, McLoughlin \& Wilson, 2012).

We end by reflecting on our digital literacies project as an application of the First Mile model of innovation (McMahon, Gurstein, Beaton, O’Donnell \& Whiteduck, 2014). In telecommunications and broadband terminology, communities are typically framed as the 'last mile' of development. The First Mile concept challenges this situation by stressing that communities be put first, which involves working with local communities to identify resources and expertise to carry forward ICT development initiatives. Drawing from engaged research

\footnotetext{
1 Research described in this article was approved by the Research Ethics Board at the University of New Brunswick.

2 This work was guided by plans and protocols jointly developed by project partners. These include a formal Memorandum of Understanding (MOU) signed by the Chiefs of Timiskaming and Long Point that outlines how we are presenting project data and methods in this journal article. This MOU is presented in Appendix 1.
} 
methodologies, collaborators jointly shape the scope, focus and outcomes of research so that projects emerge from the locally determined needs of participating communities. The next step involves building relationships among communities and regional community intermediary organizations to share resources and lessons, and extend projects to new partners. First Mile projects thus emerge from the unique circumstances of diverse communities, while also providing opportunities to scale up local initiatives through collaboration. In this paper, we discuss how the knowledge and processes about digital literacies developed with Indigenous peoples through our project contribute to this First Mile model of innovation.

\section{Framing Digital Literacies as Expressions of Indigenous Resurgence}

Over the past decade, understandings of 'digital literacies' have shifted from a focus on technical skills and knowledge to also encompass the much broader set of social literacies that people use to engage with the platforms and applications of the network society (Rheingold, 2012). For example, compare the Computer Use Complexity Scale developed by Employment and Social Development Canada (2007) with a report from the Canadian Council on Learning (2009). The Complexity Scale focuses on five levels of increasingly complex technical tasks tied to the specialized use of software and hardware, while the Canadian Council of Learning's report stresses the effective use of such tools in situated social settings, described as 'digital environments'.

This more social practice-oriented definition of digital literacies is reflected in works by scholars like White and Le Cornu (2011), who provide a strong illustration of it in their study of ICT use by 'Digital Visitors' and 'Digital Residents'. They discuss the ways that people use ICTs for both discrete tasks (Digital Visitors) and as platforms of ongoing social engagement (Digital Residents). From this perspective digital literacies encompass the integration of social practices and technical skills. Gillen and Barton (2010) similarly tie digital literacies to the varied practices that people use to navigate our increasingly connected lives:
"As digital technologies have spread, matured and developed, more people are participating in the creation and collaboration that have become characteristic of the Web 2.0 wave....The distinction between software engineering and the use of 'applications' has become more blurred as so many more users have become actively engaged in the creation of applications" (pp.4-5).

The field of Community Informatics (CI) takes this insight as a starting point for research and practice (Gurstein, 2000). CI projects seek to identify and leverage the knowledge, resources and skills held by members of communities to inform technology development and use (Longford, Clement, Gurstein \& Regan Shade, 2012). For CI researchers and practitioners, "Meaningful access to new ICTs calls for the development of a complementary social infrastructure of access to accompany the technical one" (ibid, p.16). In this context, ICTs are malleable resources that people can appropriate to meet their self-determined needs. Efforts to build digital literacies are therefore not only a means to transfer technical knowledge about 
ICTs to people, but provide knowledge and tools that people can use to adopt and adapt ICTs to fit their lived realities.

As reflected in research undertaken by the First Nations Innovation project (FNI), Indigenous peoples are leaders in such efforts to shape ICT development to meet community needs (see for example O'Donnell, Johnson, Kakepetum-Schultz, Burton, Whiteduck, Mason, Beaton, McMahon \& Gibson, 2013). ${ }^{3}$ This may in part be due to their awareness about the potential negative impacts of externally-driven ICT development initiatives. Some studies frame ICT development and use in Indigenous communities as a trade-off between 'traditional' and imposed cultures. For example, one paper discussing digital inclusion among the Orang Asli peoples of Malaysia argues that: "being digitally inclusive is not an easy process as minorities, particularly the indigenous people or 'orang asli' would have to sacrifice some aspects of their culture or lifestyle” (Hashim, Idris, Ustadi, Merican \& Fuzi, 2012, p.80).

To address this challenge, CI research stresses the need for university-based researchers to partner with community-based researchers to support mutually beneficial projects. This practice reflects suggestions made by proponents of Indigenous methodologies. For example, in her landmark book Decolonizing Methodologies, Tuhiwai Smith (2012) calls for a critical understanding of the assumptions, motivations and values that inform research projects involving Indigenous peoples. Researchers should situate their work in particular cultural and social systems, while recognizing that colonialism continues to impact Indigenous peoples. Further, Indigenous projects necessarily involve community members developing and carrying out their own research agendas. In the context of CI projects, such an approach involves partners working together to jointly facilitate the conditions that give rise to effective ICT development and use in a community (Ramirez et al., 2005). This perspective can contribute to efforts to Indigenize digital literacies, since the voices of community members are engaged in research design, interpretation and application, therefore providing them a means to embed aspects of ownership and control of ICT development and use in their communities.

A strong example of this approach is the Ktunaxa Nation Community Learning Centres project in British Columbia (Stacy, Wisener, Liman, Beznosova, Novak Lauscher, Ho and Jarvis-Selinger, 2014). This three-year partnership involved three First Nations located the traditional territory of the Ktunaxa Nation, and the eHealth Strategy Office in the University of British Columbia's Faculty of Medicine. These research partners worked together to build Community Learning Centres (CLCs) as local hubs for Internet access, and an online community focused on health education. The project was one component of the Ktunaxa Nation's strategic plan to shape and use ICT for broader community goals, including to

\footnotetext{
3 The First Nation Innovation (FNI) research project started in September 2006. Based at the University of New Brunswick (UNB) and funded through the Social Sciences and Humanities Research Council (SSHRC), it is a partnership with several regional First Nations technology organizations, including K-Net Services (part of the Keewaytinook Okimakanak tribal council in Ontario), the First Nation Education Council in Quebec, and the Atlantic Canada First Nations Help Desk, part of the Mi'kmaq Kina'matnewey educational organization in Nova Scotia. The project examines broadband communications in remote and rural First Nation communities in Canada, and explores new ways to work together in participatory research when partners are separated by vast distances. For more information, please visit: $\underline{\mathrm{http}} \mathrm{// \textrm {fn }}$-innovation-pn.com and $\underline{\mathrm{http}} \mathrm{///}$ firstmile.ca
}

Engaged Scholar Journal: Community-Engaged Research, Teaching and Learning 
preserve language and address health priorities. Utilizing a participatory research design, university-based partners engaged local facilitators to set up and manage the CLCs. These facilitators conducted surveys and interviews to identify health priorities and develop online health resources that met community needs. The communities retained ownership and control of the research process and outcomes, and took a flexible development approach to ensure that the project evolved in response to changing needs. Over time, they worked to integrate the initiative into the social realities of the communities, expanding the project's scope to encompass the research process itself as a tool for community empowerment.

Framed as a CI project informed by Indigenous resurgence, the Ktunaxa CLC initiative reflects both the social practice orientation towards digital literacies, and the desire of Indigenous peoples to secure control over technology developments that impact their communities. In this way, it seeks to embed the continual renewal of Indigenous communities in the everyday use of ICT resources.

Along with benefits associated with this kind of CI work, researchers have identified several challenges. These include: the differing goals and expectations of researchers; unequal power relations in the design and implementation of research; and practical challenges stemming from project roles, processes and outcomes (Hollander, 2009; Lang et al., 2012; McKemmish et al., 2012). Further, the diverse nature of Indigenous communities has led some researchers to conclude that no two community-engaged Indigenous research partnerships are alike (Adam \& Faulkhead, 2012). In the next section, we reflect on our two digital literacies research projects in Quebec, and consider the lessons they illustrate with regards to these challenges. Similar to the Ktunaxa project, these initiatives evolved from household surveys designed to learn about digital literacies in Timiskaming and Long Point, to ongoing efforts to integrate digital literacies in the social practices of community members. In the course of this work we encountered several challenges that illustrate the need for digital literacies projects to undertake a flexible research methodology and a strong grounding in Indigenous resurgence.

\section{Project 1: Digital Literacies Research with Timiskaming First Nation}

Our Timiskaming digital literacies project comprises a partnership between UNB, FNEC, and the Education Department of Timiskaming First Nation. The partners connected through Tim Whiteduck, Technology Director at FNEC, which is an FNI research partner with UNB, and provides ICT services to Timiskaming. Arlene Chasle, Education Director at Timiskaming, wanted to build local capacity to more effectively utilize ICT - particularly in the area of education - and held early discussions with FNEC on this topic. The three partners - including Rob McMahon from UNB (now at the Faculty of Extension at the University of Alberta) - began jointly developing a digital literacies project in Summer 2014. Arline from the Timiskaming Education Department was interested in gathering data from community members regarding their use of and interest in ICT, and then using that data to inform the community's strategic technology plan. As well, the availability of local technology support is a challenge due to a lack of trained staff, and so the Education Department was interested in building digital literacies to increase engagement in ICT tools among community members. In 
this context the project became a natural opportunity to both learn about existing ICT capacities and resources held by the community, and to collect information to help Timiskaming develop digital literacy workshops shaped to local interests and needs. Because Tim Whiteduck's primary objective was to establish a baseline on the level of technology infrastructure and use in the community, the research was also seen as a planning tool to help determine what services the organization needs to focus on and plan for the future. Rob McMahon at UNB sought to develop academic outputs related to Indigenous ICT development and use. Following the FNI publication policy, these outputs would be co-authored with the community, with the topics, focus and argument of papers determined collaboratively by the partners. ${ }^{4}$

Drawing on experience and knowledge gained from earlier FNI projects, the team used multi-site videoconferencing technologies to support ongoing research discussions from remote locations (Gratton \& O'Donnell, 2011) and undertook field trips to build relationships (Gibson, Thomas, O’Donnell, Lockhart \& Beaton, 2012). We began by establishing a formal relationship between university-based researchers, community leadership, and FNEC. This involved jointly preparing a proposal to guide our research, which was formally approved by Chief and Council through a signed MOU, after a presentation in the community. FNI researchers are required to develop formal agreements with community partners prior to any field research being conducted. This is done to provide: background on project collaborators; a summary of community and university research interests; project objectives and deliverables; project method and research approach; and a work plan. The team engaged a local project liaison to guide fieldwork planning and help develop project methods, analysis, interpretation, and deliverables. We spent a lot of time developing these relationships and project resources, with many changes along the way.

Our experience highlights the need for CI projects to remain flexible. The project methodology evolved over the course of our discussions. We decided to work with local high school students to conduct household surveys about digital literacy, access, connectivity, and effective use of ICTs in Timiskaming. We designed the survey as a communication tool as well as a data-gathering instrument. This was done to raise awareness about different aspects of effective ICT use and digital literacies in the community - a focus is in line with methods undertaken by other FNI project researchers (see Beaton \& Carpenter, 2014; Beaton, Seibel $\&$ Thomas, 2014). To raise community awareness of the survey, and of digital literacies more generally, we promoted the project in an article in the local Kiwetin school newsletter, and also through word of mouth.

A field visit in late October 2014 launched the survey project. The team presented to local high school students and service providers (education and health staff, Band Office employees, and Band Councilors, among others). At each presentation we solicited feedback to improve the work moving forward. For example, during a discussion with teachers at the local elementary school, participants raised several important points that helped shape the project, including questions regarding community ownership and control of research data.

4 To read the FNI publication policy, please visit: http:// firstmile.ca/resources/sharing-resources/ 
The visit also finalized the project MOU, which was reviewed and approved by Chief and Council after a presentation led by Tim Whiteduck. At the request of Arline Chasle from Timiskaming, we also added a second round of surveys tailored to community services to further support community ICT planning.

The fieldwork activities helped raise awareness of digital literacies among several different sectors of the community, and also contributed to the project research methodology. As a result of our discussions, we invited 10 high school students to collect data through doorto-door surveys delivered to approximately 208 homes (roughly 20 houses each). Each student was given an individualized information package that included a brief explanation of the survey and a prize draw ballot for an iPad (an incentive for respondents). ${ }^{5}$ Audrey McLaren, the coordinator for Timiskaming's Education Partnerships Program, managed the students and worked with teachers to ensure that their volunteer hours would be accepted as graduation credits. The project offered several other incentives for students, including honoraria; experience in community-based research; a reference letter; and the opportunity to be acknowledged by name (if they wished) in publications resulting from survey data.

One youth researcher also got involved in early-stage data analysis. Dana McLeod, a co-op student working at the Band office, helped the team input survey data into an online program (Survey Monkey). This allowed Timiskaming to retain control of project data and remotely share survey results with the university researcher through the online platform. Through this project, Dana gained training in data entry methods, which also helped speed up data analysis.

We emphasize that this research process unfolded in an unpredictable manner, with lots of setbacks and unexpected developments. We faced challenges in retaining youth researchers: as time passed, some students were unable to complete their household surveys. Many people in the community spend time away from home, which complicated attempts to distribute surveys to all households. At the suggestion of the community partner, to address this situation we hired a local adult to distribute remaining surveys. This person was paid from the project budget. These experiences further illustrate the need for a flexible, emergent methodology that is integrated in the shifting realities of life of the community - and the practical research challenges that can arise in the course of data collection and analysis.

The long-term nature of our revised project provided us with opportunities to conduct additional public outreach on digital literacies. To this end we re-framed the household surveys as 'community questionaires', which have a different focus, methodology and approach than 'scientific surveys'. Rather than drawing on a representative or randomized sample of a given population, a community questionaire seeks to engage as broad a population as possible. This allowed us to use the surveys as communication tools as well as data-gathering instruments. To this end, we extended the data collection phase of the project to ensure that all households in the community participated in the survey. This aim is distinct from scientific sampling

\footnotetext{
5 We recognize the challenges and bias that may emerge through the use of student researchers. For example, respondents may feel compelled to answer questions. As well, in small, tight-knit communities, respondents may feel uncomfortable answering sensitive questions. That said, our questions avoided sensitive issues, and we told students they would receive credit regardless of whether all their surveys were answered or not. We designed the survey research to alleviate these challenges.
} 
methods that focus on a relatively small number of randomly chosen individuals, or online surveys emailed to respondents in a chosen population group. Undertaking the project this way fit the team's focus on using the survey process itself as a tool to raise awareness of digital literacies among community members.

The public outreach impact of this process not only supported our goal of building digital literacies in Timiskaming. It also generated a higher-than-average survey response rate among the First Nation respondents - a population group historically less likely to participate in surveys undertaken by external researchers (see Health Canada, 2012). According to our calculations, $45 \%$ of eligible respondents in Timiskaming completed our surveys (176 of 391 eligible individuals). ${ }^{6}$ This high response rate reflects that of other community-based First Nation research partnerships, contributing to growing evidence that community-engaged approaches result in increased participation in research (for example see: Latycheva et al., 2013). ${ }^{7}$

Once we completed the surveys, and after discussion among project researchers, the team decided to base our analysis on two data sets: a general analysis of all 176 survey results; and a comparative analysis seperated into three age categories: "Youth" (18-34 years; 58 responses); "Adults" (35-54 years; 82 responses); and "Seniors" (55-65+ years; 41 responses). When we separated our survey data into these three age categories, distinctions emerged with regards to how people use technology, attitudes about technology, issues of access and affordability of technology, and other issues. These findings will help Timiskaming's Education Department design and promote ICT workshops to different segments of the community. They also sparked ideas for follow-up projects. For example, Timiskaming's Education Department is interested in learning more about local Internet service providers, such as what speeds they offer, how reliable their services are, and what a monthly residential Internet plan costs. This information can be shared in the community to ensure that residents are aware of local Internet service. It may also support the community's efforts to advocate for more equitable rates and quality of service guarantees.

During a second field visit, we met in person to discuss the next steps for the project.

\footnotetext{
6 According to the most recently available federal government records, the total population of Timiskaming First Nation is 2,074 (AANDC, 2014). Of this total population, in April 2015 Aboriginal Affairs and Northern Development Canada (AANDC) lists 583 people registered as living on-reserve (294 males; 289 females). Slightly older AANDC statistics (from 2011) indicate that the total population of registered Indians on the reserve was 490 people ( 240 male; 245 female), of which $39 \%$ (190 people) were between $0-19$ years of age. We estimate the number of minors (0-17 years of age) in 2011 as approximately one-third (33\%, which is $6 \%$ less than the $0-19$ population) of the total population. For the purpose of this project, we estimate that a similar ratio of one-third (33\%) of the total population of registered Indians living on-reserve in April 2015 will be minors (0-17 years of age). Therefore, of the 583 people registered as living on-reserve at the time of the Timiskaming survey (2015), approximately 192 will be minors - and therefore not eligible to take the household survey. This leaves us with 391 eligible survey respondents.

7 In total, 176 people responded to our household survey. Of these, 91\% indicated that they lived on-reserve. However, upon consultation with Timiskaming partners, we learned that the $9 \%$ of people who indicated they do not live on-reserve do live in the community - just on parcels of land that do not hold the same legal status as reserve land. Therefore, we jointly decided to include all 176 of the survey respondents, since they live within the place-based boundaries of the reserve, and are registered members of the Band. All of these respondents are 18 or older (they indicated their age on the completed surveys).
} 
These included presenting our findings at the annual conference of the Canadian Sociological Association, held in June 2015 at the University of Ottawa. Representatives from all three partners attended the conference, with our presentation equally divided between Shelley Chief (a member of Timiskaming Council who holds the Education portfolio), Tim Whiteduck from FNEC, and Rob McMahon from UNB. We also discussed how Arline and Audrey from the Timiskaming Education Department could present the household survey results in a community newsletter.

The team also discussed lessons learned through our project, including the need to hire an on-site community researcher to coordinate local data collection and analysis; to adopt a flexible methodology that allows for changes; and to adapt research outcomes, recognizing that both process and results can be purposed in many different ways. These discussions informed the adoption of our research methodology for a similar project in the nearby Algonquin community of Long Point, which we discuss in the next section.

\section{Project 2: Digital Literacies Research with Long Point First Nation}

As the digital literacies project in Timiskaming was underway, Rob McMahon and Tim Whiteduck started a similar initiative with Long Point First Nation, another Algonquin community located a few hours drive from Timiskaming. Long Point First Nation is as Anishinabeg community located in the unceded territory of Anishnabe Aki. The First Nation has approximately 800 members - around half of whom live within the community. In terms of ICT infrastructure, it currently has fibre connectivity in place for public service organizations, and FNEC is working with the community on a fibre optic expansion project to improve household Internet connectivity and affordability. The community also recently completed construction of a new school - at the time the research was conducted many students bussed to a community located one hour away.

Tim Whiteduck had approached Leonard Polson (Education Director) and Henry Rodgers (Principal at Amo Ososwan School) in Long Point to work together on a digital literacies project that adapted the methodology used in Timiskaming. Similar to that project, the Long Point initiative was jointly developed by the three partners and approved by Chief and Council through a signed MOU, clarified after several discussions and meetings. As a first step, Tim Whiteduck and Rob McMahon presented findings and lessons learned from Timiskaming to local leadership. We noted the project involved a long-term partnership that adapted over time due to logistical setbacks experienced by the community researchers. We also stressed the importance of hiring a community-based project coordinator, and also setting up that person's role as encompassing public outreach as well as research activities.

The Long Point team decided to adapt existing research materials from Timiskaming (with permission from that community). While employing a similar method - household surveys conducted by community-based researchers - the Long Point team had different project goals. Specifically, Leonard and Henry wanted to collect and analyze survey data to inform technology planning for the new school. Based on the team's discussions, we modified the questions and added several new ones on topics such as whether people in the community are 
interested in cellular service, what kinds of technology parents would like to see in the new school, what community leadership can do to meet household demands for Internet, and how community leadership can ensure that ICT is accessible to everyone in the community.

The household survey process also drew on - but adapted - the approach developed in Timiskaming. The project researchers developed a series of tools: project consent forms, a bank of survey questions, and a 'how-to' guide for local researchers. We modified these resources to meet the community's interests. The team decided to distribute household surveys to 80 households in the community and several off-reserve homes. Incentives for students and respondents remained the same: a gift card and letter of recognition for students, and a prize draw for an iPad for survey respondents. We hired a community research coordinator, Audrey Polson, to help with distributing surveys and inputting data into Survey Monkey through a customized link created by Rob McMahon at UNB. As in Timiskaming, all survey data remains the property of Long Point First Nation, with UNB and FNEC asking permission to use it for academic or other outputs decided on in consultation with the community. Articles and other outputs are co-authored with Tim Whiteduck, Leonard Polson and Henry Rodgers, who had the opportunity to review them before publication.

A field visit to Long Point in Spring 2015 to introduce the project included meeting with the Chief, Leonard and Henry, and potential student participants. During this visit the Long Point partners suggested that the team issue regular memos and other communication materials to keep the community informed about the project. This idea helped us build awareness of digital literacies in the community. We hired Audrey Polson as a local research coordinator, and put together household survey toolkits that include instructions, surveys, prize draw receipts, and a 'to do' checklist. We also approached student researchers to distribute and collect the surveys.

When put into practice, much like in Timiskaming, the survey process in Long Point unfolded in an unpredictable manner. The local students initially involved in the project declined to participate later on. This may be due to several factors. Fewer students live in Long Point, and those who do are younger than those in Timiskaming (in Grades 9, 10 and 11). These younger students also do not require community service credits as part of their coursework. The survey project in Long Point also took place in summer, a time when many students are away on holidays or working. Given this situation, similar to Timiskaming, Audrey, the local community research coordinator, completed survey distribution.

Due to other commitments, once data collection was completed Audrey was unable to continue with the project. The team identified another community member, a local Youth ICT Worker named Alexia Pichette, to contribute to data entry work. Alexia completed inputting the data into Survey Monkey, and as in Timiskaming, the team jointly analyzed the survey data and produced reports that the Long Point team might use to inform community projects moving forward. Similar to in Timiskaming, this project resulted in some interesting data regarding ICT use in the community, raised local awareness of digital literacies, and provided community-based researchers with experience in designing, conducting and interpreting a survey project. Tim Whiteduck is planning a return visit to Long Point to present the results of the household survey, including this article, to Henry, Leonard and others in the community. 
Reflecting on commonalities and contrasts between the two digital literacies projects, it is clear that in community engaged research with Indigenous peoples, no two partnerships are alike (Adams \& Faulkhead, 2012). The First Nations partners in Timiskaming and Long Point each had different ideas regarding the focus, process and outcomes of their digital literacies projects. The two communities also had different resources available to support their involvement. In Timiskaming, the project engaged a full-time research coordinator who was on staff at the Education Department, as well as a number of local youth, including a co-op student who worked at the Band office. In Long Point, the researchers benefitted from the involvement of two local adults, who organized youth engagement, public outreach, and data collection and analysis for the project. The communities also shared information about their projects with one another, and the planning discussions helped the project team develop ICT research toolskits that are now available to other communities interested in learning about and promoting digital literacies. These resources include a process to plan household surveys, a list of potential survey questions, and other research tools such as survey consent forms. The team has also presented these tools to another Indigenous community and to researchers affiliated with the FNI project for consideration in their own digital literacies projects.

\section{Building Digital Literacies in Communities: From Research Outcomes to Research Process}

The First Mile model of innovation (Paisley \& Richardson, 1998; Strover, 2000) provides a conceptual framework we use to reflect on our engaged research project methodology, and proposes a series of steps that other researchers can apply in similarly focused initiatives. McMahon et al. (2014) describe a two-step model of First Mile innovation that involves first working with local communities to identify resources and expertise to carry forward ICT development initiatives. Project collaborators in engaged research jointly shape the scope, focus and outcomes of research. The next step involves building relationships among communities. This includes partnering with regional community intermediary organizations such as FNEC to access expertise, economies of scale, advocacy support and other benefits of larger-scale aggregation. This two-step process highlights how First Mile projects emerge from the unique circumstances of diverse communities, while also providing opportunities to scale up local initiatives through regional collaboration, such as knowledge-sharing between Timiskaming and Long Point. Table 1 compares aspects of the engaged research process that we adapted in our First Mile project with more conventional approaches. 
Table 1: Steps in Engaged Research Process

\begin{tabular}{|c|c|c|}
\hline & Engaged research process & $\begin{array}{l}\text { Conventional research } \\
\text { process }\end{array}$ \\
\hline $\begin{array}{l}\text { Research } \\
\text { Conceptualization }\end{array}$ & $\begin{array}{l}\text { - Communities as co-researchers } \\
\text { who work with university- } \\
\text { based researchers to leverage } \\
\text { their internal resources and } \\
\text { capacities over a period of } \\
\text { months }\end{array}$ & $\begin{array}{l}\text { - Communities as research } \\
\text { subjects studied by outside } \\
\text { 'experts', often for a fixed } \\
\text { period of time }\end{array}$ \\
\hline Research Design & $\begin{array}{l}\text { - Upfront, reciprocal and } \\
\text { collaborative engagement with } \\
\text { the community actors who } \\
\text { drive project relevance and } \\
\text { sustainability } \\
\text { - Case studies and community } \\
\text { engagement activities focus on } \\
\text { situated processes rather than } \\
\text { generalizable findings }\end{array}$ & $\begin{array}{l}\text { - Research designed by } \\
\text { university-based researchers, } \\
\text { sometimes independent } \\
\text { from community input } \\
\text { - Standardized research } \\
\text { can support generalizable } \\
\text { findings }\end{array}$ \\
\hline Data Gathering & $\begin{array}{l}\text { - Engage community actors in } \\
\text { data gathering to facilitate the } \\
\text { conditions that give rise to } \\
\text { effective ICT development and } \\
\text { use }\end{array}$ & $\begin{array}{l}\text { - External researchers } \\
\text { conduct data-gathering } \\
\text { activities }\end{array}$ \\
\hline $\begin{array}{l}\text { Data Analysis and } \\
\text { Synthesis }\end{array}$ & $\begin{array}{l}\text { - Actively incorporate the voices } \\
\text { of community members in } \\
\text { data analysis and proposing } \\
\text { solutions to policy or practical } \\
\text { challenges } \\
\text { - Co-constructed findings can } \\
\text { support culturally appropriate } \\
\text { research and ethical } \\
\text { imperatives to reduce harm }\end{array}$ & $\begin{array}{l}\text { - Analysis is conducted } \\
\text { by institutional experts, } \\
\text { typically external from the } \\
\text { community } \\
\text { - This is to maintain } \\
\text { objectivity and reduce } \\
\text { interpretive bias }\end{array}$ \\
\hline
\end{tabular}




\begin{tabular}{|l|l|l|}
\hline Research Outcomes & $\begin{array}{l}\text { Communities retain ownership, } \\
\text { control, access and possession } \\
\text { (OCAP) over project data and }\end{array}$ & $\begin{array}{l}\text { - Universities or other } \\
\text { research organizations } \\
\text { extract informational } \\
\text { resources held by } \\
\text { Ontcomes } \\
\text { - Partnerships with regional } \\
\text { community intermediary } \\
\text { organizations enables } \\
\text { communities to access } \\
\text { expertise, economies of } \\
\text { scale, advocacy support and } \\
\text { other benefits of larger-scale } \\
\text { aggregation. }\end{array}$ \\
\hline
\end{tabular}

As noted earlier, Indigenous peoples have long argued that they must drive research and development agendas (Tuhiwai Smith, 2012). Over the years, Indigenous organizations and their research partners in universities have developed ways to support communities in developing and retaining project processes, data and outcomes, as expressed in the formal principles of Ownership, Control, Assess and Possession (OCAP) (Assembly of First Nations, 2007; FNIGC, 2014; Schnarch, 2004). Such engaged research aims to provide opportunities for the multi-directional transfer of skills and knowledge between community-based and universitybased researchers. This principle of reciprocity includes support for Indigenous ownership in and control over research data and outcomes.

In Canada, this focus is also reflected in the ethical conduct required of researchers by federal funding agencies. For example, Chapter 9 (Research Involving the First Nations, Inuit and Métis peoples of Canada) of the 2nd edition of the Tri-Council Policy Statement: Ethical Conduct for Research Involving Humans points out the importance of trust, communication, mutually beneficial research goals, appropriate research collaborations or partnerships, and ethical conduct in research with Indigenous peoples (Canadian Institutes of Health Research, Natural Sciences and Engineering Research Council of Canada, and Social Sciences and Humanities Research Council of Canada, 2014).

Observing OCAP principles means that university-based and community-based researchers can shape collaborative projects over time to involve all partners from the earliest stages of project conception and design, through to the analysis and dissemination of results. Communities retain ownership of research data and project deliverables, and universities request permission to use these materials for jointly-authored research and public outreach materials. University-based partners benefit from this process, since the community knowledge they draw on is collected, interpreted and validated by involved people. This supports efforts to conduct appropriate and relevant research. Community-based researchers also offer invaluable logistical support for field visits, connect university-based researchers with local contacts, manage interviews, and act as guides. Importantly, these various activities and process come 
together in long-term and ongoing partnerships that explore how projects and their outcomes might be integrated in the lived realities of community members. Table 2 illustrates the benefits of this multi-directional process.

Table 2: Benefits of Engaged Research Process

\begin{tabular}{|c|c|c|}
\hline & $\begin{array}{l}\text { For University-based } \\
\text { researchers }\end{array}$ & $\begin{array}{l}\text { For Community-based } \\
\text { researchers }\end{array}$ \\
\hline $\begin{array}{l}\text { Formal Research } \\
\text { Protocols }\end{array}$ & $\begin{array}{l}\text { - Establish relationship based } \\
\text { on clarity, respect and trust } \\
\text { - Clarify roles and } \\
\text { responsibilities }\end{array}$ & $\begin{array}{l}\text { - Establish relationship based } \\
\text { on clarity, respect and trust } \\
\text { - Clarify roles and } \\
\text { responsibilities }\end{array}$ \\
\hline $\begin{array}{l}\text { Discussions on } \\
\text { Nature, Scope, and } \\
\text { Focus of Research }\end{array}$ & $\begin{array}{l}\text { - Organizational and logistical } \\
\text { support for field research } \\
\text { - Connect with local contacts }\end{array}$ & $\begin{array}{l}\text { - Benefit from research } \\
\text { outcomes } \\
\text { - Ensure research meets local } \\
\text { needs }\end{array}$ \\
\hline $\begin{array}{l}\text { Involving Community } \\
\text { Members in Data } \\
\text { Collection and } \\
\text { Analysis }\end{array}$ & $\begin{array}{l}\text { - Local support for research } \\
\text { activities } \\
\text { - Validation of culturally } \\
\text { appropriate research }\end{array}$ & $\begin{array}{l}\text { - Capacity-building in research } \\
\text { activities } \\
\text { - Local employment }\end{array}$ \\
\hline $\begin{array}{l}\text { Guidelines on } \\
\text { Collection and Use } \\
\text { of Research Data and } \\
\text { Outcomes }\end{array}$ & $\begin{array}{l}\text { - Fulfill research ethics } \\
\text { requirements } \\
\text { - Generate academic outputs }\end{array}$ & $\begin{array}{l}\text { - Retain OCAP over data and } \\
\text { outcomes }\end{array}$ \\
\hline
\end{tabular}

As discussed throughout this paper, the dynamic and uncertain nature of ICT development and use makes digital literacies research and practice a necessarily fluid endeavor. The rapid speed of technological innovation often outpaces that of research activity - particularly in projects that aim to provide concrete, sustained benefits for involved communities. Furthermore, the unique contexts present in diverse communities means that digital literacies projects must be adaptable and flexible: practical setbacks can emerge in the course of research. In this paper we described several unexpected developments that occurred during our projects with Timiskaming and Long Point. We also discussed how community engaged methodologies support research partners in identifying and leveraging the resources and capacities already held by communities to address these challenges.

The theoretical framework of Indigenous resurgence provides strong lessons for how research partners located in universities and in communities can generate mutually beneficial projects. It provides a perspective that stresses the importance of weaving Indigenous knowledge, resources and learning into the fabric of research initiatives created in partnership 
with communities. This approach provides important lessons for all kinds of communityengaged research projects. Indigenous resurgence can help increase project sustainability over time, while meeting ethical imperatives to practice respectful research. It can also generate high levels of project relevance and sustainability among community members. For all these reasons and more, practices of Indigenous resurgence will be of interest to communityengaged researchers working in a wide range of contexts.

\section{Acknowledgements}

The authors express their thanks to Dr. Susan O'Donnell and Brian Beaton from the First Nations Innovation (FNI) project for their support, suggestions and feedback on the project and methodology described in this paper. We also thank the reviewers and editors of a special issue of the Journal of Community Informatics, in which some components of this paper were initially published. Arline Chasle and Audrey McLaren from Timiskaming First Nation were instrumental in coordinating local research there, while Shelley Chief joined the team to present our findings in June 2015 at the Congress of the Social Sciences and Humanities at the University of Ottawa. In Long Point First Nation, Leonard Polsen and Henry Rodgers led the local research team, which included Audrey Polson who distributed household surveys and Alexia Pichette who input the results into Survey Monkey. We thank students from Timiskaming and Long Point for their help in distributing and collecting household surveys, including Victoria Chevrier and Dana McLeod, who gave consent to be named in this article. Dana also helped with data input and analysis. Finally, we thank the anonymous reviews of this article, and the editors of the Engaged Scholar Journal, for their constructive feedback on an earlier version of this article. This paper is a result of the partners and communities involved in the FNI research project based at the University of New Brunswick (http://fninnovation-pn.com / http://firstmile.ca). The FNI project is funded by the Social Sciences and Humanities Research Council of Canada, with in-kind contributions from the project partners: Keewaytinook Okimakanak (www.knet.ca), the First Nations Education Council (www.cepn-fnec.com), Atlantic Canada's First Nation Help Desk / Mi'kmaw Kina'matnewey (www.firstnationhelp.com), the University of New Brunswick (www.unb.ca) and the University of Alberta (www.ualberta.ca). 
About the Authors

Arline Chasle, Education Director, Timiskaming First Nation

Shelley Chief, Education Councillor, Timiskaming First Nation

Rob McMahon (corresponding author), Assistant Professor, Faculty of Extension, University of Alberta. Email: rdmcmaho@ualberta.ca

Leonard Polson, Education Director, Long Point First Nation

Henry Rodgers, Principal, Amo Ososwan School, Long Point First Nation

Tim Whiteduck, Technology Director, First Nations Education Council

\section{References}

AANDC - Aboriginal Affairs and Northern Development Canada. (2014). Aboriginal peoples \& communities - First Nation profiles (Timiskaming). Retrieved from http://pse5-esd5.ainc-inac. gc.ca/fnp/Main/Search/FNListGrid.aspx?lang=eng

Adam, K., \& Faulkhead, S. (2012). This is not a guide to Indigenous research partnerships. Information, Communication \& Society, 15(7), 1016-1036.

Alfred, T., \& Corntassel, J. (2005). Being Indigenous: Resurgences against contemporary colonialism. Government \& Opposition, 40, 597-614.

Assembly of First Nations. (2007). OCAP: Ownership, control, access and possession - First Nations inherent right to govern First Nations data. Ottawa: Assembly of First Nations. Retrieved from: http://64.26.129.156/misc/ocap.pdf

Beaton, B., Seibel, F. \& Thomas, L. (2014, May). Valuing the social economy and information and communication technologies (ICT) in small remote First Nations. Paper presented at the annual conference of the Association of Social Economy and Non-Profit Research, St. Catherines, Ontario.

Beaton, B., \& Campbell, P. (2014). Settler colonialism and First Nations e-communities in Northwestern Ontario. Journal of Community Informatics, 10(2). Retrieved from http:/ / cijournal.net/index.php/ciej/article/view/1072/1089

Beaton, B. \& Carpenter, P. (2014, May). A critical understanding of adult learning and education using information and communication technologies (ICT) in remote First Nations. Paper presented the annual conference of the Canadian Association for Study of Indigenous Education, St. Catherines, Ontario. 
Canadian Council on Learning. (2009). State of E-learning in Canada. Ottawa: Canadian Council on Learning.Retrieved on March 15, 2015 from: http://www.ccl-cca.ca/pdfs/E-learning/ELearning_Report_FINAL-E.PDF

Canadian Institutes of Health Research, Natural Sciences and Engineering Research Council of Canada, and Social Sciences and Humanities Research Council of Canada, Tri-Council policy statement: Ethical conduct for research involving humans. Ottawa: Secretariat on Responsible Conduct of Research. Retrieved from: http://www.pre.ethics.gc.ca/pdf/eng/tcps2-2014/ TCPS_2_FINAL_Web.pdf

Carpenter, P., Gibson, K., Kakekaspan, C., O’Donnell, S. (2013). How women in remote and rural First Nation communities are using information and communication technologies (ICT). The Journal of Rural and Community Development, 8(2), 79-97.

Employment and Social Development Canada. (2007). Computer use complexity scale. Gatineau: Essential Skills Research Unit, Skills and Labour Market Information Division, Skills and Employment Branch, Employment and Social Development Canada. Retrieved from http://www.esdc. gc.ca/eng/jobs/les/profiles/readersguide.shtml\#h2.9

First Nations Information Governance Centre (FNIGC). (2014). Barriers and levers for the implementation of OCAPTM. The International Indigenous Policy Journal, 5(2). Retrieved from http://ir.lib.uwo.ca/iipj/vol5/iss2/3

Gibson, K., Thomas, L., O’Donnell, S., Lockhart, E., \& Beaton, B. (2012, June). Co-creating community narratives: How researchers are engaging First Nation community members to co-write publications. Paper presented at the Qualitative Analysis Conference, St. John's, NL.

Gillen, J. \& Barton, D. (2010). Digital literacies: A research briefing by the technology enhanced learning phase of the teaching and learning research programme. Lancaster: Literacy Research Centre, Lancaster University. Retrieved from http://www.tlrp.org/docs/DigitalLiteracies.pdf

Gratton, M.-F., O’Donnell, S. (2011). Communication technologies for focus groups with remote Communities: A case study of research with First Nations in Canada. Qualitative Research, 11(2), 159-175.

Gurstein, M. (2000). Community informatics: Enabling communities with information and communications technologies, Hershey, USA: Idea Group Publishing.

Haas, A. (2014). Toward a decolonial digital and visual American Indian rhetorics pedagogy. In J.R. Anderson, R. Gubele \& L. King (Eds.), Survivance, sovereignty, and story: Teaching American Indian rhetorics (pp.188-208). Logan: Utah State University Press.

Hashim, R., Idris, K.S., Ustadi, Y.A., Merican, F.M. \& Fuzi, S. (2012). Digital inclusion and lifestyle transformation among the Orang Asli: Sacrificing culture for modernity? Asian Social Science, $8(12), 80-87$.

Health Canada. (2012). First Nations and Inuit eHealth Infostructure Program (eHIP) evaluation (Final report), Ottawa: Health Canada. Retrieved May 8, 2015 from: http:/ /www.hc-sc.gc.ca/ahc-asc/ performance/eval/2012/ fni-evaluation-pni-eng.php

Hollander, J.B. (2009). Keeping control: the paradox of scholarly community-based research in community development. Community Development Journal, 46(2), 265-272.

Jones. A. \& Jenkins, K. (2008). Rethinking collaboration: Working the Indigene-colonizer hyphen. In N.K. Denzin, Y.S. Lincoln \& L.T. Smith (Eds.), Handbook of critical and Indigenous methodologies (pp.471-483). Los Angeles, London, New Delhi, and Singapore: Sage. 
Lang, C., Stillman, L., Linger, H., Dalvean,, J., McNamara, B., McGrath, J., \& Collins, R. (2012). Collaborative research partnerships in the community. Information, Communication \& Society, 15(7), 1081-1105.

Latycheva1, O., Chera1, R., Hampson, C., Masuda, J.R., Stewart, M., Elliott, S.J., Fenton, N.E. (2013). Engaging First Nation and Inuit communities in asthma management and control: Assessing cultural appropriateness of educational resources, Rural and Remote Health, 13, 1-11.

Longford, G., Clement, A., Gurstein, M. \& Regan Shade, L. (2012). Connecting Canadians? Community informatics perspectives on community networking initiatives. In A. Clement, M. Gurstein, G. Longford, M. Moll and L.R. Shade (Eds.), Connecting Canadians: Investigations in community informatics (pp.3-32). Edmonton: Athabasca University Press.

McKemmish, S., Burstein, F., Faulkhead, S., Fisher, J., Gilliland, A.J., McLoughlin, I., \& Wilson, R. (2012). Working with communities. Information, Communication \& Society, 15(7), 985-990.

McMahon, R., Gurstein, M., Beaton, B., O’Donnell, S., Whiteduck, T. (2014) Making information technologies work at the end of the road. Journal of Information Policy, 4, 250-269.

O’Donnell, S., Johnson, L., Kakepetum-Schultz, T., Burton, K., Whiteduck, T., Mason, R., Beaton, B., McMahon, R. \& Gibson, K. (2013). Videoconferencing for First Nations communitycontrolled education, health and development. Electronic Journal of Communication, 23(1\&2).

Paisley, L. and Richardson, D. (1998). Why the first mile and not the last? In L. Paisley \& D. Richardson (Eds.), The First Mile of connectivity: Advancing telecommunications for rural development through a participatory communication approach (pp. 2-13). Rome: Communication for Development Rome: Food and Agriculture Organization of the United Nations (FAO). Retrieved from: http://www.fao.org/docrep/x0295e/x0295e03.htm

Ramirez, R., Aitkin, H., Kora, G., and Richardson, D. (2005). Community engagement, performance measurement, and sustainability: Experiences from Canadian community-based networks. Canadian Journal of Communication, 30(2), 259-279.

Rheingold, H. (2012). Net smart: How to thrive online. Cambridge, MA: MIT Press.

Schnarch, B. (2004). Ownership, control, access, and possession (OCAP) or self-determination applied to research: A critical analysis of contemporary First Nations research and some options for First Nations communities." Journal of Aboriginal Health, 1: 80-95.

Simpson, L. (2011). Dancing on our turtle's back: Stories of Nishnaabeg re-creation, resurgence and a new emergence. Winnipeg, Canada: Arbeiter Ring Publishing.

Stacy, E., Wisener, K., Liman, Y., Beznosova, O., Novak Lauscher, H., Ho, K., \& Jarvis-Selinger, S. (2014). Community-based research in action: Tales from the Ktunaxa community learning centres project. Progress in Community Health Partnerships: Research, Education, and Action, 8(3), 281-290.

Strover, S. (2000). The first mile. The Information Society, 16(2), 151-154.

Tuhiwai Smith, L. (2012). Decolonizing methodologies: Research and Indigenous peoples (2nd edition.). London and New York: Zed Books.

White, D.S. \& Le Cornu, A. (2011). Visitors and residents: A new typology for online engagement. First Monday, 16(9). Retrieved March 16, 2015 from: http://firstmonday.org/ojs/index.php/ $\mathrm{fm} / \mathrm{rt} /$ printerFriendly/3171/3049 